\title{
Contribution For Improvement Of Rice Breeding Programs Through Morphoanatomical Traits
}

\author{
Germani Concenço (Corresponding author) \\ Embrapa Clima Temperado, Sustainable Cropping Systems, \\ Rod. BR 392 Km 78 s/n, Pelotas-RS, Brazil \\ Tel: +555332758493Ｅ-mail: germani.concenco@embrapa.br
}

Giovani Greigh de Brito

Embrapa Soja, Plant Physiology, Rod. Carlos João Strass s/n,

Warta, Londrina-PR, Brazil

Tel: +554333716100Ｅ-mail: giovani.brito@embrapa.br

Paulo Roberto Reis Fagundes

Embrapa Clima Temperado, Rice Breeding,

Rod. BR 392 Km 78 s/n, Pelotas-RS, Brazil

Tel: +555332758431Ｅ-mail: paulo.fagundes@embrapa.br

\author{
Walkyria Bueno Scivittaro \\ Embrapa Clima Temperado, Soil Science, \\ Rod. BR 392 Km 78 s/n, Pelotas-RS, Brazil \\ Tel: +555332758210Ｅ-mail: walkyria.scivittaro@embrapa.br
}

\begin{abstract}
José Maria Barbat Parfitt
Embrapa Clima Temperado, Agroclimate and Irrigation,

Rod. BR 392 Km 78 s/n, Pelotas-RS, Brazil

Tel: +555332758444Ｅ-mail: jose.parfitt@embrapa.br
\end{abstract}


Thais Stradioto Melo

Federal University of Pelotas, Institute of Botany,

Campus Universitário Capão do Leão-RS, Brazil.

Tel: +555332758493Ｅ-mail: thais.stradioto1@gmail.com

Laryssa Barbosa Xavier da Silva

Federal University of Pelotas, Institute of Botany,

Campus Universitário Capão do Leão-RS, Brazil.

Tel: +555332758493Ｅ-mail: laryssaxavier2@gmail.com

\author{
Sidnei Deuner \\ Federal University of Pelotas, Department of Plant Physiology, \\ Campus Universitário Capão do Leão-RS, Brazil. \\ Tel: +555332757337_E-mail: sdeuner@yahoo.com.br
}

Received: January 26, 2021

Accepted: April 6, $2021 \quad$ Published: April 10, 2021

doi:10.5296/jas.v9i2.18256

URL: https://doi.org/10.5296/jas.v9i2.18256

\begin{abstract}
Breeding programs aim to increase grain yield and quality through selection oriented mostly by morphological and productive traits. Although morphoanatomical traits are preponderant for plant performance, they are usually time-consuming, demanding specific equipment and trained personnel. The aim of the study is to establish relationships among morphological, micromorphological and anatomical traits of rice genotypes, to support rice breeders in choosing variables to be assessed in the search for superior rice genotypes. We assessed morphological ( $2^{\text {nd }}$ leaf and root lengths, tiller and root number), micromorphological (vein density, intervein distance, stomatal density and opening width) and anatomical (area of sclerenchyma, xylem and phloem vessels, and percentage of aerenchyma) traits. Root number and length, area of sclerenchyma and xylem and phloem vessels are proposed to be the most efficient traits to be assessed in detailed studies aiming to identify superior genotypes in rice breeding programs, from the morphophysiological point of view.
\end{abstract}

Keywords: anatomy, morphology, Oryza sativa, physiology, plant performance 


\section{Introduction}

Rice is a staple food for about half the world, and together with crops as maize, wheat and potatoes, helps guaranteeing the human demand for calories and nutrients (Fukagawa \& Ziska, 2019). Substantial gains in both rice grain yield and quality were reached due to improved breeding techniques and local adjustments of management practices (Alam et al., 2013; Khan et al., 2014).

Generally, breeding programs aim to increase crop grain yield and quality through selection procedures that seek at individual and community plant levels, oriented mostly by morphological and productive traits (Fukagawa \& Ziska, 2019). It is, however, a consensus the remarkable contribution of morphoanatomical traits for plant performance (Abdusalam \& $\mathrm{Li}, 2018$ ). Traits of this nature are usually time-consuming, also demanding specific equipment and trained personnel to be assessed. It can be challenging to assess morphoanatomical traits of a large number of genotypes, if only limited staff and equipment is available.

Radosevich et al. (2007) described the importance of plant vigorous early development for competition against weeds and other plant species. In general terms, those who emerge first and grow faster will take the lead and use most of the environmental and input resources available (Fageria \& Moreira, 2011; Zain et al., 2014), considering a community leading strategy based on dominance (Avolio et al., 2019). Although growth parameters can be inferred from biometric measures, as plant height and leaf area, most detailed assessments are demanded as breeding programs find even more challenging to keep increasing rice grain yield and quality beyond the current levels. Morphological aspects of rice plants as high growth rates, early tillering and high leaf area, thus, may be decisive for rice plant performance in production fields (Feldman et al., 2017; Bertolino et al., 2019).

Furthermore, micromorphological traits as stomatal density and caliber may affect gas exchange rates and, therefore, greatly contribute to superior plant physiological performance (Bertolino et al., 2019). Xylem and phloem caliber are also determinant on the ability of transporting substances as water, nutrients, proteins, sugars and informational molecules, from the anatomical point of view (Lucas et al., 2013; Bayley \& LeeGood, 2016), working in close cooperation with stomatal regulation.

Caine et al. (2019) report the impact of plant micromorphology on rice performance, focusing on stomatal aspects. These authors present evidences that proper stomatal density and dimension may improve plant ability of gas exchange, reducing water loss with improved $\mathrm{CO}_{2}$ assimilation. Furthermore, stomatal interaction with xylem and phloem ability in conducting substances, as well as with aerenchyma, may prove to affect gas exchange rates and as a result the overall plant physiological performance (Colmer, 2003).

Other morphoanatomical aspect known to interfere on plant physiology is the vein density in rice leaves (Feldman et al., 2017). According to these authors, rice genotypes with higher vein density in leaf blade tend to perform better, probably when coupled to adequate caliber on xylem and phloem vessels (Lucas et al., 2013; Eom et al., 2013; McAdam et al., 2017). 
The main aim of the study is to establish relationships among morphological, micromorphological and anatomical traits of rice genotypes from the same breeding program, in a way to support rice breeders in choosing morphoanatomical variables to be assessed in the search for superior genotypes, and consequently, superior rice cultivars in grain yield levels and tolerance to abiotic factors.

\section{Method}

\subsection{Experimental Design and Management}

The experiment was carried out at Embrapa Clima Temperado, Terras Baixas experimental station, located in Capão do Leão, Rio Grande do Sul, Brazil, in the 2019/2020 growing season, in randomized blocks design with four replications. Each plot was constituted by a rectangular $500 \mathrm{~L}$ fiberglass water tank, equipped with independent valve-controlled water inlets and outlets for precise irrigation and drainage as needed. Tanks were filled with a $5 \mathrm{~cm}$ layer of crushed stone followed by a $5 \mathrm{~cm}$ layer of coarse sand, and a $50 \mathrm{~cm}$ layer of a Planossolo (Typic Albaqualf) previously corrected and fertilized for rice crop (Rice Commission, 2018).

Treatments consisted of seven commercially available rice varieties with recognized superior performance, plus 57 rice lineages from Embrapa's breeding program, planted in $1 \mathrm{~m}$ long rows spaced in $0.175 \mathrm{~m}$, thinned to the density of 300 plants $\mathrm{m}^{-2}$ ten days after emergence. The cycle length of the 64 genotypes (emergence to harvest) varied from 110 to 135 days. Genotypes were distributed in different tanks according to their cycle length, to standardize management practices. Planting was accomplished in 23/Sep./2019, and emergence occurred in 02/Oct./2019.

Topdressing fertilization consisted of $125 \mathrm{~kg} \mathrm{ha}^{-1}$ of $\mathrm{N}$ as commercial urea split in three applications: $15 \mathrm{~kg} \mathrm{ha}^{-1}$ of $\mathrm{N}$ at the 2-leaf stage (V2); $60 \mathrm{~kg} \mathrm{ha}^{-1}$ of $\mathrm{N}$ at the 4 to 5-leaf stage, prior to flooding, and the remaining $40 \mathrm{~kg} \mathrm{ha}^{-1}$ of $\mathrm{N}$ applied at panicle initiation. This stage was estimated using the software Planejarroz (Embrapa/UFSM, 2019) by supplying location, emergence date and indicating a commercial variety with approximately similar cycle length.

Irrigation was managed in the alternate wetting and drying (AWD) system (Sriphirom et al., 2019). All plots were irrigated daily to keep soil moist, from rice sowing to the beginning of tillering (4 to 5-leaf stage). In this phase, a $7 \mathrm{~cm}$ water layer was established and maintained for 10 days aiming not to interfere in nitrogen uptake by rice plants. Then, the first AWD cycle started. For that, the plots were not irrigated again until soil water tension reached $20 \mathrm{kPa}$. At this water tension, a new $7 \mathrm{~cm}$ water layer was established and maintained for three days, starting a new soil drying cycle, always having the soil water tension of $20 \mathrm{kPa}$ as the threshold for reflooding (Pinto et al., 2020). AWD cycles were repeated until ripening begun. Soil water tension was monitored by installing Watermark ${ }^{\circledR}$ sensors (Irrometer inc., USA) in each plot. These were wired to electronic data loggers for continuous follow up on soil water status. Data was reviewed twice a day.

Spontaneous weeds in the plots were eliminated by hand; insects were controlled by a single application of $14 \mathrm{~g} \mathrm{ha}^{-1}$ of zeta-cypermethrin, eight days after emergence (DAE), and no later 
insecticide application was needed. Diseases occurrence were also negligible for all genotypes, not demanding any control measures.

\subsection{Morphological Assessments}

Morphological analysis of plants were done 22 DAE. For each replication and genotype, 2 rice plants ( 8 plants per treatment) were collected, deposited into a glass with water, and immediately taken to the lab where the $2^{\text {nd }}$ leaf (first expanded leaf) and root lengths were measured, and tiller and root number were counted. Leaf length was measured with graduated ruler from leaf collar to its tip; root length was measured from seed insertion to the longest root tip. After assessments, the second leaf (first expanded leaf) was removed for the micromorphological analysis.

\subsection{Micromorphological Assessments}

The middle section of the adaxial (upper) face of the second leaf was observed and photographed in optical microscope (Nikon e200) in two magnifications: $0.5 \mathrm{x} / 4 \mathrm{x}$ and $0.5 \mathrm{x} / 40 \mathrm{x}$, respectively for camera and objective lens, resulting in $2 \mathrm{x}$ and $20 \mathrm{x}$ total magnifications. Leaf was gently pressed between microscope slide and the glass cover slip, held together by lateral adhesive tapes, to keep leaf flat open. Photography scales were set by previously capturing images of a microscope calibration ruler, in both magnifications. Two images with resolution of $2048 \times 1536$ pixels (3.1 MP) were taken per leaf, in different areas, for later analysis.

Images were saved in hierarchical naming structure for later processing, which was accomplished using the software ImageJ v.1.53c (NIH, 2020). After the proper software scale calibration, the vein density, inter-vein distance $(2 \mathrm{x}$ magnification - Figure 1), stomatal density and opening width (20 x magnification - Figure 2 ) were measured using the proper software tools. Stomatal related data were obtained after applying the filter "relief" to the images to increase stomatal border and opening contrasts (Figure 2). Stomata number was counted in an area correspondent to $25 \%$ of the captured image, as this was the area into each picture where the microscope was better focused. This area was properly considered in stomatal density calculations. Scales were reported into images by ImageJ.

\subsection{Anatomical Assessments}

Leaf samples were collected for anatomical assessments 110 DAE. A section of $10 \mathrm{~cm}$ of leaf was cut from the middle third of the second leaf of rice plants, being obtained two samples per replication and genotype. These samples were put into acrylic flasks and fully covered with alcohol $70 \%$, sealed and stored into refrigerator at $5 \pm 2{ }^{\circ} \mathrm{C}$. The solution was exchanged weekly during four weeks, to remove part of the green pigment chlorophyll, and later the assessments were performed.

Leaf sample was cut by hand with good quality razor blade, after insertion in maize stem cortex, to facilitate cuttings by immobilizing the rice leaf sample. About 30 thin straight cuttings, transversal to leaf length, were obtained per sample. Cuttings were dispersed into a Petri dish containing clean water; the two thinner cuttings of the rice leaf were chosen, 


\section{Macrothink}

Journal of Agricultural Studies

ISSN 2166-0379

2021, Vol. 9, No. 2

transferred to a microscope glass slide and added a drop of clean water, being later covered with a glass cover slip and taken to the microscope for image capture.

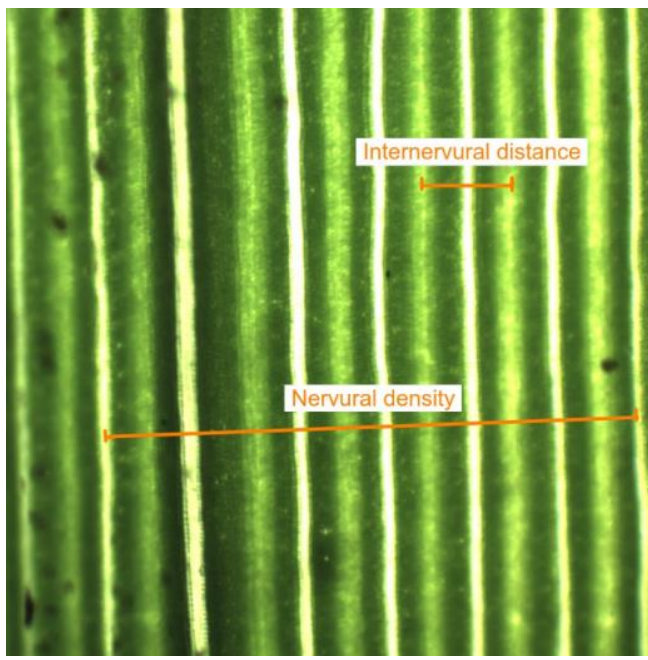

Figure 1a. Magnification of the adaxial (upper) surface of the second rice leaf, collected 22 days after emergence, through a $4 \mathrm{x}$ microscope objective lens.

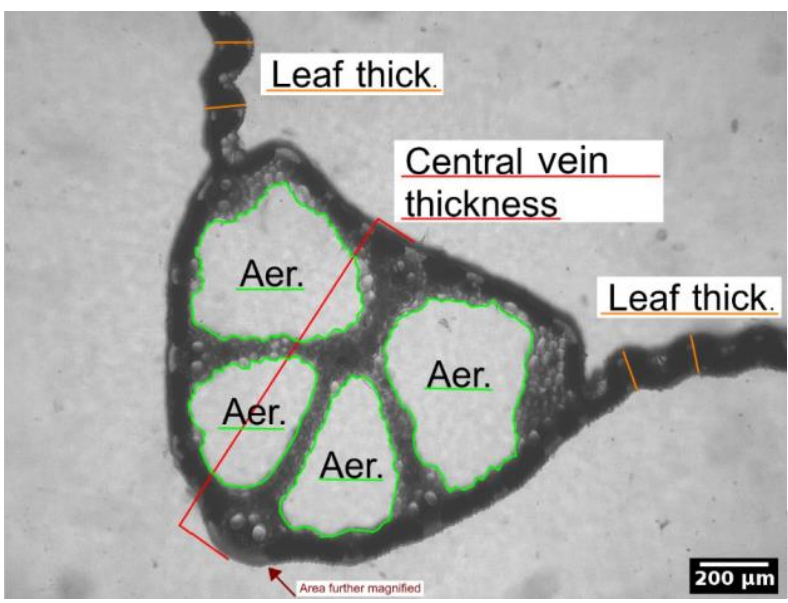

Figure 2a. Cross section of the central part of the second rice leaf, collected 110 days after emergence, through a $4 \mathrm{x}$ microscope objective lens.
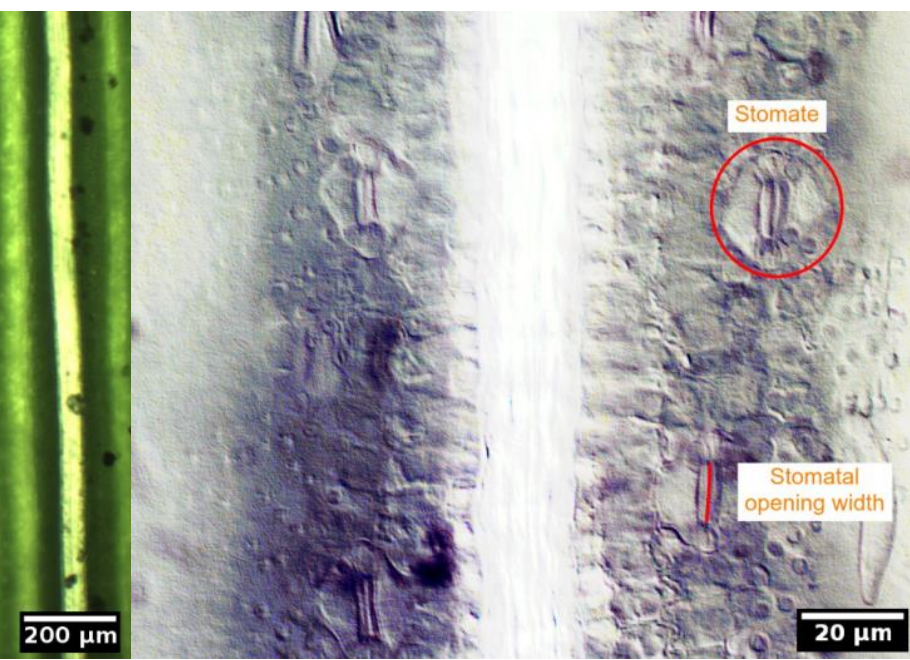

Figure 1b. Magnification of the adaxial (upper) surface of the second rice leaf, collected 22 days after emergence, through a 40x microscope objective lens, after application of the filter "relief" for edges sharpening.

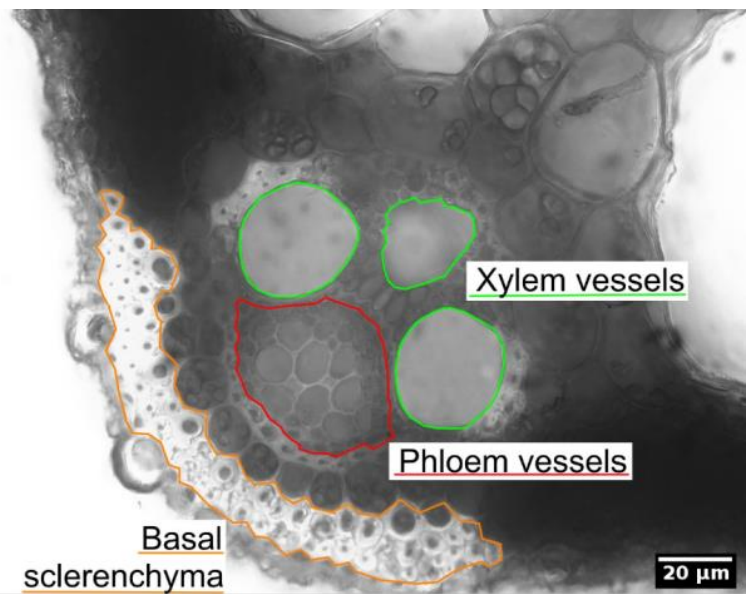

Figure $2 \mathrm{~b}$. Bottom vascular bundle of the cross section of the central part of the second rice leaf, collected 110 days after emergence, through a 40x microscope objective lens.

Images were obtained in the same equipment and magnifications described for 
micromorphological analysis. Images were also assessed in the software ImageJ v.1.53c, after proper software scale calibration. The percentage of aerenchyma in the central vein of rice leaf (Figure 3) was assessed in pictures taken at 2 x magnification, while xylem and phloem vessels, as well as sclerenchyma areas, were reported from pictures with $20 \mathrm{x}$ magnification (Figures 3, 4), for the basal vein of the central vein.

\subsection{Statistical Analysis}

All statistical analysis were run into the $R$ environment ( $R$ development team, 2020), by using commands made available by the packages "ExpDes" and "stats", respectively for the univariate and multivariate analysis.

Data mining began by investigating all data sets in terms of ANOVA assumptions - normality and variance homogeneity of errors. After elimination of a few outliers, these assumptions were met. All variables were submitted to analysis of variance by the F-test at $5 \%$ probability. In case of significance, treatment means were grouped by Scott-Knott at $5 \%$ and data was presented in Figures where green $(\square$, yellow $(\square)$ and red $(\square)$ bars represented the first, second and third mean groups, respectively.

After the univariate analysis, each variable into the data set was transformed into percent basis (0 - 100), verified again for normality of errors, and submitted to multivariate analysis of principal components (PC's), by the command "prcomp". The multivariate analysis were executed respecting their requirements, as reported by Fendler et al. (2001). Data was presented in pattern plot, where the first and second PC's were mapped to " $x$ " and " $y$ " axis, respectively.

\section{Results}

All variables were significant at $\mathrm{p} \leq 0.05$ in the univariate ANOVAs. Furthermore, the pattern PCA analysis was able to group variables as function of the two main principal components.

\subsection{Morphology}

The 2nd rice leaf blade length measured 22 DAE was superior only in 14 genotypes, out of 64 , with average value corresponding to $\sim 8.3 \mathrm{~mm}$ for the superior group, and $\sim 7.9 \mathrm{~mm}$ for the remaining genotypes (Figure 3a).

Rice genotypes were pooled in two groups in terms of root length (Figure 3b), with 26 genotypes presenting roots $\sim 40 \%$ longer than the remaining 38 genotypes. Similar behavior was reported for root number (Figure 3c), where 28 genotypes presented longer roots at magnitudes of $\sim 30 \%$. Only 16 genotypes $(25 \%)$ presented both longer and more abundant roots (Figures $3 b ; c)$.

Only four genotypes, among the 64 tested ones, were able to tiller earlier in the experimental conditions (Figure 1d), with two of them presenting three tillers and the other two presenting 2.5 tillers on average.

\subsection{Micromorphology}

Rice leaf veins (set of vascular bundles) are arranged in parallel, longitudinally to leaf length 
(Figure 1a). Between veins there is a region with high density of bulliform cells. As leaves are most transparent in the strip of bulliform cells, veins are visible by passing a calibrated light beam through the leaf.

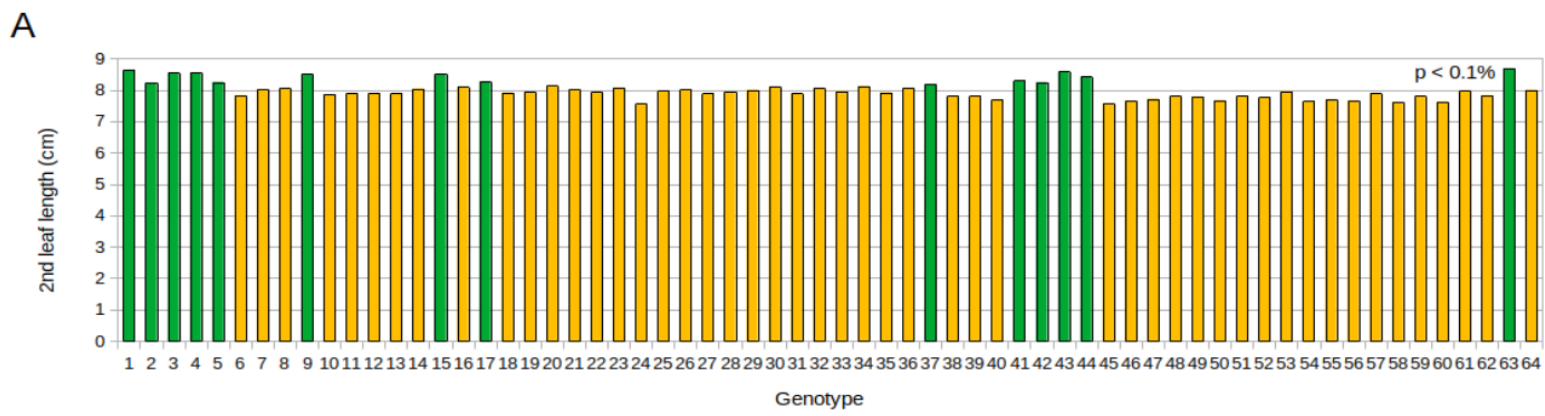

B

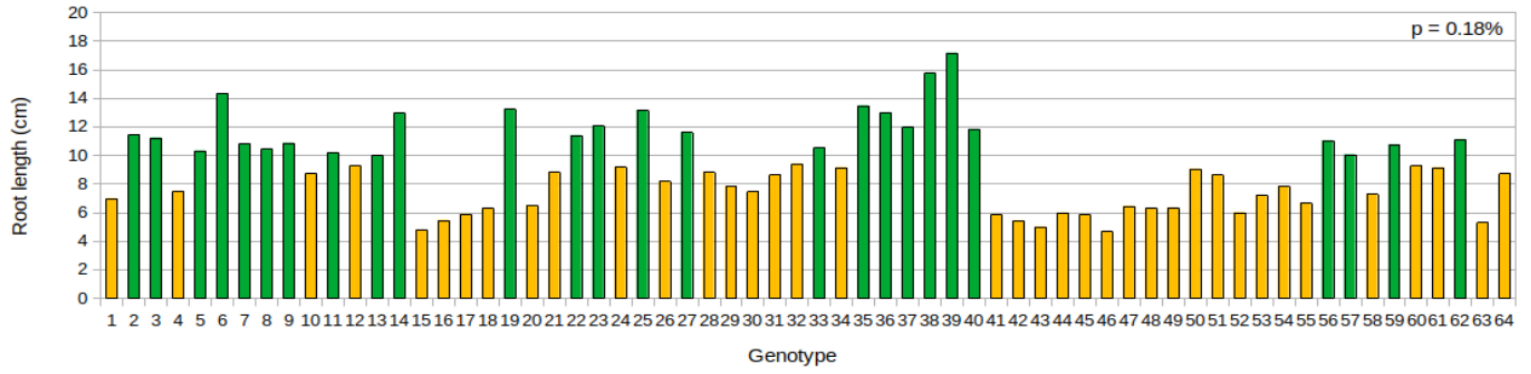

C
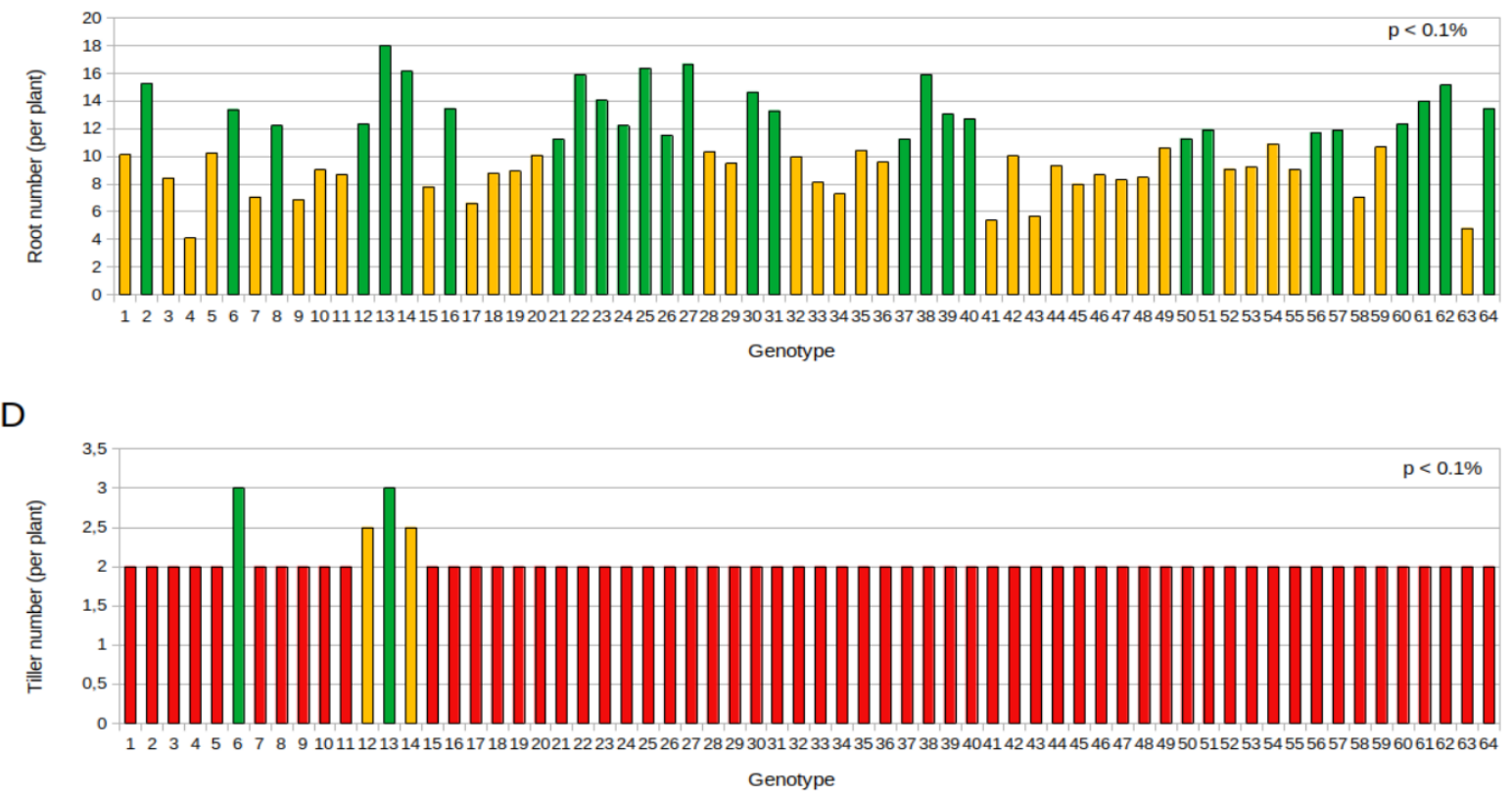

Figure 3. Morphological traits assessed 22 days after emergence in rice genotypes from the same rice breeding program at Embrapa Clima Temperado, Pelotas-RS, Brazil. Green ( $\square$ ), yellow ( $\square$ ) and red (\) bars represent the first, second and third mean groups, respectively, according to Scott-Knott at $5 \%$ probability. 
Vein density differed among rice genotypes (Figure $4 \mathrm{a}$ ), with 37 genotypes (58\%) presenting $\sim 6$ veins per mm of leaf width, while the second group of genotypes presented $\sim 5.4$ veins per mm of leaf width (Figure 4a). Most of the genotypes presenting lower vein density, however, also had higher vein thickness (Figure 4b); the remaining width is fullfilled by bulliform cells. This seems to act as a compensation point, where lower vein density is mostly coupled to thicker veins. Genotypes 7, 14 and 54, however, were able to couple higher inter-vein density with higher caliber veins (Figures 4a;b), probably at the cost of lower volume of bulliform cells.

Our data highlight that stomatal density (SD) was higher for 21 genotypes $\left(\sim 500\right.$ stomata $\left.\mathrm{mm}^{-2}\right)$, while the remaining 43 genotypes presented $\sim 408$ stomata $\mathrm{mm}^{-2}$ of leaf (Figure $4 \mathrm{c}$ ) - a reduction of $\sim 20 \%$ on SD compared to the first statistical group, according to Scott-Knott's.

In the present study, the stomatal width (SW) was also measured, with 23 genotypes presenting SW about $25 \%$ higher than the others (Figure 4d). Superior SD is coupled to smaller SW for 14 genotypes out of 64 (Figures 4c;d), supplying a set of genotypes for breeding, considering the new evidences on SD and SW relationships and consequences for water use efficiency (Bertolino et al., 2019; Caine et al., 2019).

Xylem vessel area was one of the variables with greater difference among genotypes, that were pooled into three groups (Figure 5a). Xylem vessels caliber were on average $\sim 800$; $\sim 580$ and $\sim 385 \mathrm{~mm}^{2}$ per vessel, respectively, for the superior, middle and inferior groups formed by Scott-Knott's (Figure 5a). Our analysis, however, did not consider possible differential vessel densities among genotypes.

\subsection{Anatomy}

Phloem is the main responsible for carbohydrates reallocation and movement of signaling substances from source to sink organs, supporting plant growth and development (Eom et al., 2012). The area of phloem vessels bundle (Figure 5b) was also stratified in three groups, whose areas were $\sim 2050, \sim 1478$ and $\sim 1116 \mathrm{~mm}^{2}$, for the superior, middle and inferior groups, respectively.

As xylem and phloem widely cooperate in an orchestrated organization to supply the demand for water, carbohydrates, proteins, signaling substances and others in different parts of the plant, their dimensions should be compatible to each other. In these terms, coupled superior caliber for xylem and phloem vessels bundles were reported to be present in 17 genotypes, out of 64 (Figures 5a;b).

The percentage of aerenchyma in the central leaf vein (Figure 5c) differed among genotypes, with two distinct groups. The first group, with 14 genotypes, presented $\sim 34 \%$ aerenchyma, while the second group, with 50 genotypes, presented $29 \%$ (Figure 5c). Aerenchyma is preponderant on rice ability to deal with waterlogged or flooded soil and plays an important role in gas diffusion to parts of the plant located into the water zone (Colmer, 2003; Xu et al., 2018). 


\section{Macrothink}

Journal of Agricultural Studies ISSN 2166-0379

2021, Vol. 9, No. 2

The genotypes were pooled into three groups regarding the area of sclerenchyma in the basal portion of leaf vein: respectively with $\sim 3500 ; \sim 2500$ and $\sim 1300 \mathrm{~mm}^{2}$ of sclerenchyma for the first, second and third genotype groups (Figure $5 \mathrm{~d}$ ).
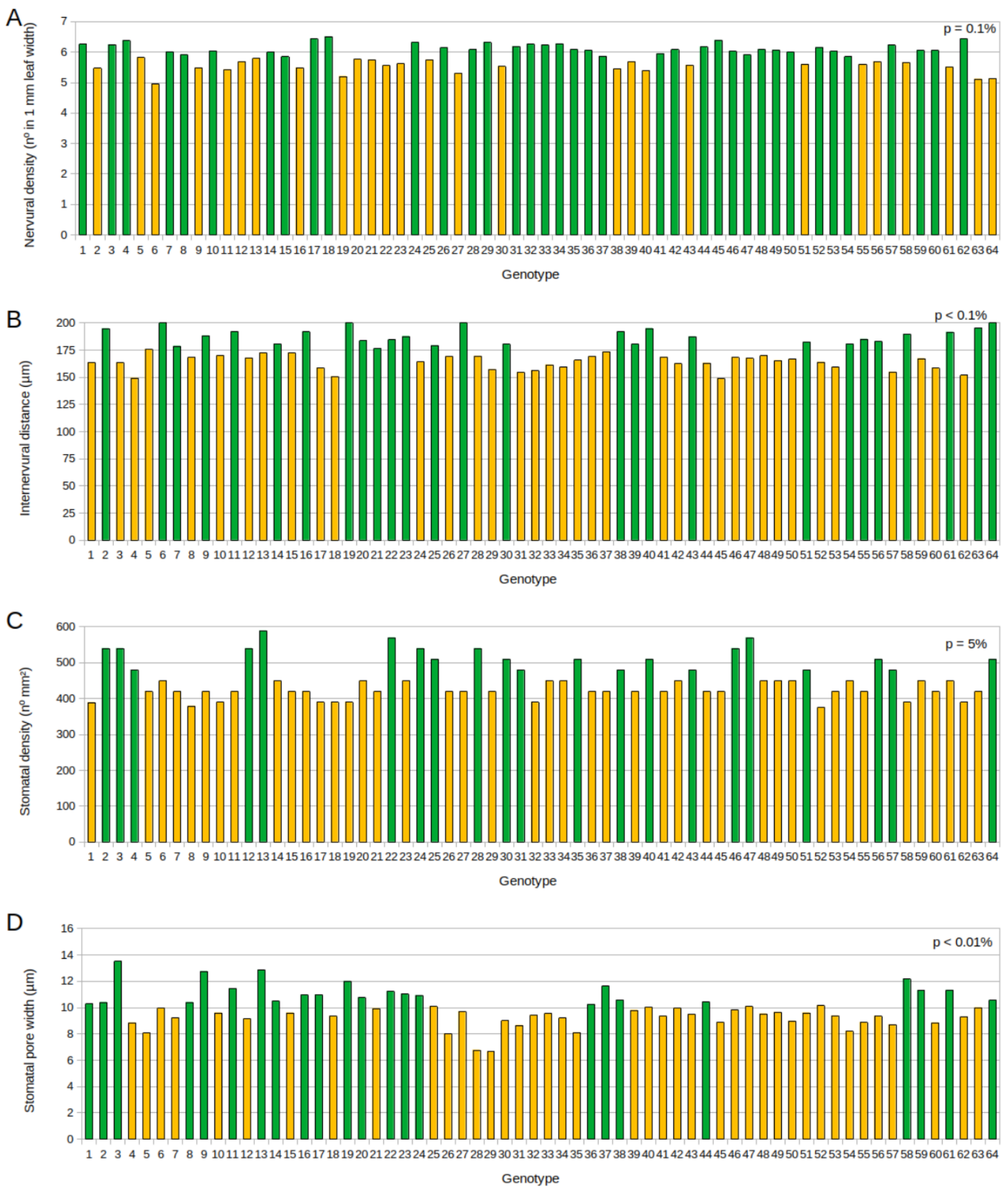

Figure 4. Micromorphological traits assessed 22 days after emergence in rice genotypes from the same rice breeding program at Embrapa Clima Temperado, Pelotas-RS, Brazil. Green ( ) and yellow ( $)$ bars represent the first and second mean groups, respectively, according to Scott-Knott at 5\% probability. 


\section{A Macrothink}

Journal of Agricultural Studies

ISSN 2166-0379

2021, Vol. 9, No. 2

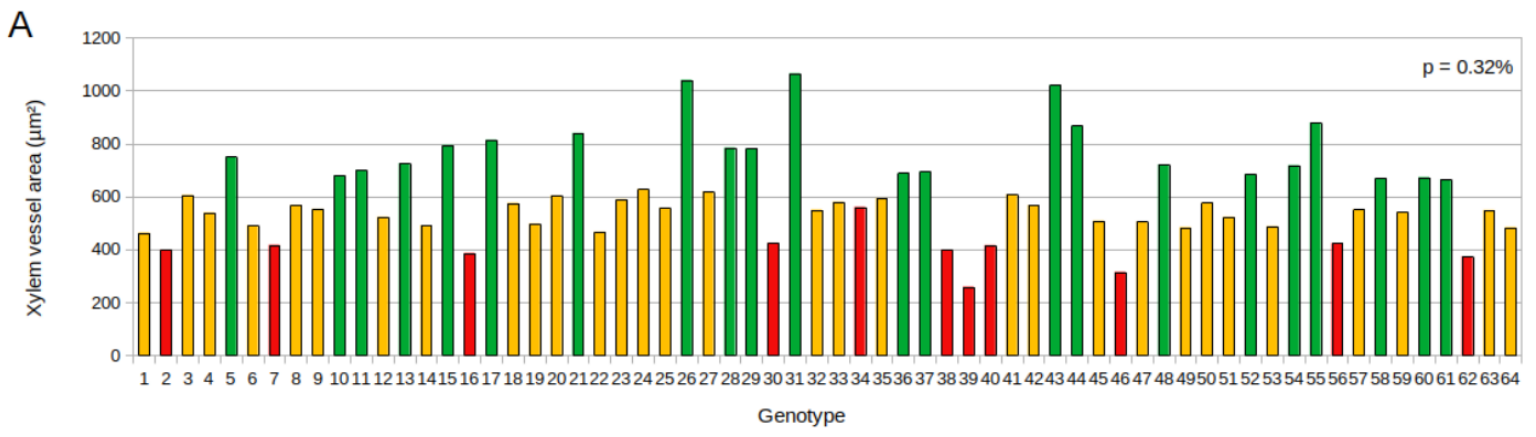

B
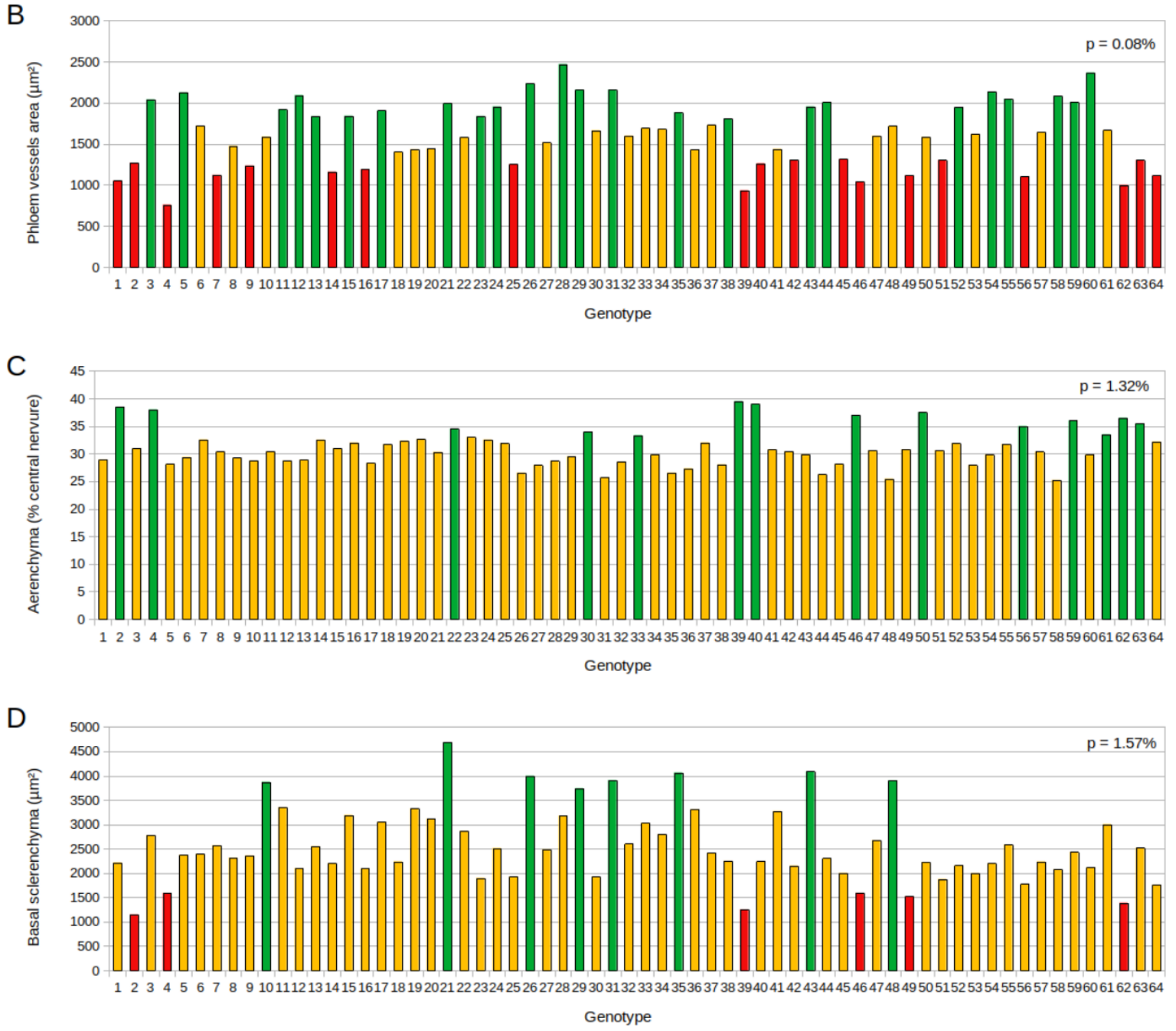

Figure 5. Anatomical traits assessed 110 days after emergence in rice genotypes from the same rice breeding program at Embrapa Clima Temperado, Pelotas-RS, Brazil. Green $(\square)$, yellow ( $\square$ ) and red (1) bars represent the first, second and third mean groups, respectively, according to Scott-Knott at $5 \%$ probability. 


\section{Discussion}

\subsection{Morphology}

The 2nd rice leaf blade length is correlated to plant height (Ranawake et al., 2013) and possibly to plant's superior ability in competing against weeds (Thiel et al., 2018), but it is hardly correlated to rice grain yield (Ranawake et al., 2013). Tivet et al. (2001) report that rice leaf length often represents superior ability in growth rates, and depends greatly on its position in the plant. Furthermore, longer leaves in the upper third of rice plants may also increase its inter- and intra-specific competitive ability (Galon et al., 2015), which can be further increased by adequate levels of nitrogen fertilizer (Zhou \& Wang, 2011).

Thicker and longer roots in rice, mainly when associated to deeper growth, may help avoiding drought stress in rice in areas where irrigation is managed in the alternate wetting and drying (AWD) system (Kim et al., 2020). Rice root length is also known to be correlated to rice grain yield levels (Fageria \& Moreira, 2011). Roots are the main plant-soil interface, and rice mineral nutrition depends mostly on its roots ability in reaching and extracting adequate amounts of nutrients from the soil (Veçozzi et al., 2018). The same authors reported that possible nutrient limitations may come not only from insufficient applied amounts, but also from the lack of coupling $\mathrm{N}$ availability with rice demand timings. Liu et al. (2018) report that for hybrid rice breeding programs, both root length and volume were correlated to grain yields, and that increases in these features also increase rice response to $\mathrm{N}$ fertilization, being thus highly desirable in rice breeding programs.

On the same way, superior tillering in rice plants may increase its competitive ability against weeds (Galon et al., 2015), and possible volunteer plants of other rice varieties (Schreiber et al., 2018), and increase the use efficiency of environmental resources (Nawaz \& Farooq, 2017). Vigorous tillering also allows rice to reach high leaf area index (LAI) earlier in the crop cycle, depending on $\mathrm{N}$ availability (Zhong et al., 2002). Zain et al. (2014) also reported that drought stress reduces rice tillering; thus, genotypes with superior tillering ability under intermittent drought stresses, as the AWD irrigation system, would perform better in grain yield. Our tillering results, however, are considered as evidence only and later studies on the theme will be conducted with the same genotypes to confirm this evidence.

\subsection{Micromorphology}

Bulliform cells are highly vacuolated and play the role of controlling leaf rolling as they inflate or dry out (Nawaz \& Farooq, 2017), helping plants to overcome drought periods. Anatomically, they can be used as markers for determining the connection point between different leaf veins.

Leaf venation is structured to take substances to and from virtually any part of the plant, depending on the source-sink relationship (Feldman et al., 2017; McAdam et al., 2017). In this sense, vein density (VD - also called venation density) and veins thickness (VT) are preponderant in constituting adequately scaled pathways for substance movement into the plant (Tabassum et al., 2016). The same authors report that, under water deficit conditions, photosynthesis rate and water conductance ability are related to the major veins' thickness. 
On the surface of the vein strips of the leaf, there are the stomata, whose main role is to act as gatekeepers in the control of gas exchange; the entry of $\mathrm{CO}_{2}$ and water loss rates through stomata are particularly important for plant metabolism (Brito et al., 2016). Stomata play a critical role in regulating plant effective use of water, what can be related to high capacity to capture water for transpiration or even acting in increase/decrease of water use efficiency (WUE); they are also involved in nutrient uptake from roots by transpiratory fluxes.

For rice, new findings supply evidence that greater stomatal density in leaves may not always be positive for the plant (Caine et al., 2019). These authors report that under simulation of climate change, an engineered rice cultivar with fewer stomata proved to be most conservative in water use, with equivalent and even higher grain yields than the original cultivar. This result, however, is hypothesized to be linked to the expected grain yield levels since it is unlikely that genotypes with grain yields superior to $10 \mathrm{t} \mathrm{ha}^{-1}$ would be benefited by lower stomatal density. This is yet to be deeper studied. Bertolino et al. (2019) report that smaller size stomata may contribute for a faster stomatal opening/closure process, also contributing for improved gas exchange equilibrium. There seems to be no clear idea if stomatal size (SS) being smaller really contributes for improved gas exchange rates, although there is a common consensus on a naturally inverse SD : SS relationship in plants (Dittberner et al., 2018). SS is often estimated from stomatal width (SW) (Bertolino et al., 2019). In this scenario, it seems most appropriate to consider as superior those genotypes with high stomatal density associated to smaller stomatal opening ( $>\mathrm{SD} /<\mathrm{SW})$.

For rice paddies grown under continuous flooding irrigation, or even when the alternate wetting and drying management is adopted under deep soil profile, prevalent traits such as higher stomatal density and stomatal opening width are associated to deep and functional roots, higher hydraulic conductance of root and shoots, lower root apoplastic barriers, plant architecture and great osmotic adjustment capacity, on the improved grain yield performance (Kato \& Okami, 2010; Eom et al., 2012; Steduto et al., 2012; Farally et al., 2019; Kim et al., 2020). These traits are not only related to genotype but interact with the environment (Poli et al., 2018); for this reason, these aspects should be taken into account by breeders in the definition of the environment target where the new genotypes will be grown. In other words, for breeding, environment matters.

In such conditions, prioritizing selection of plants carrying such traits could increase the probability to obtain cultivars with improved effective use of water capacity, which lead to maximize soil water capture for transpiration, and also can be associated to a decrease in the non-stomatal transpiration and minimizing water lost by soil evaporation.

\subsection{Anatomy}

Rice vascular system is of primary importance for plant development as it serves as pathway for environmental resources as water, nutrients and sugars, as well as acting in long distance signaling (Lucas et al., 2013). Xylem is important also for transport of inorganic and organic forms of nitrogen, amino acids and amides from roots to shoots (Bailey \& Leegood, 2016).

Transport of substances through xylem depends roughly on the difference of water potentials 
in soil and in free air, whose effect is the flux of sap through the vases, from soil to roots, shoots, leaves and finally to the air as water vapor (Marenco \& Lopes, 2008). For the transport to be effective, xylem vessels also need to be intact, free from leakage points, and vessel caliber is one of the determinants of sap flux rate through xylem (Bayley \& Leegood, 2016).

The proportion of aerenchyma in leaves is also correlated to the water management system; plants submitted to intermittent flooding, as in the AWD water management system, tend to present lower aerenchyma than continuously flooded plants (Steffens et al., 2010). Furthermore, two main mechanisms of cell lysis for aerenchyma formation are reported (Parlanti et al., 2011); cell lysis may come by production of reactive oxygen species (ROS) as $\mathrm{H}_{2} \mathrm{O}_{2}$, or alternatively by superior ethylene production. Both substances tend to impact several other morphophysiological processes into the rice plant (Steffens et al., 2010).

The amount of sclerenchyma in the central vein of rice leaf blade is another anatomical trait with links to physiological performance (Aohara et al., 2009). Sclerenchyma is the harder type of fiber that promote support for an erect leaf position (Crang et al., 2018). Erect leaves in rice may allow higher plant density in production fields while reducing intraspecific competition for light compared to decumbent leaves (Chen et al., 2015), from a community point of view.

\subsection{Multivariate Analysis}

The principal components of multivariate analysis were able to attribute $62.4 \%$ of the total variation for PC1 and $17.5 \%$ for PC2, where variables were pooled in three major groups (Figure 6). The group marked in green is smaller and includes only morphological traits, particularly root number and length, that accounted the most for both principal component axis (Figure 6). The blue marked group, on the other hand, included only anatomical traits, particularly the sclerenchyma, xylem and phloem areas at the basal vascular bundle of the central vein of rice leaf blade (Figures $2 b ; 6$ ). The red marked group included traits from a mixture of sources (morphological, micromorphological and anatomical).

Regarding the X/Y distances among groups (Figure 6), morphological traits accounted more both for PC1 and PC2, while the anatomical ones accounted heavily only for PC1. Considering that PC1 accounted for most of the variation (62.4\%), morphological traits are most preponderant in pooling rice genotypes, followed by anatomical traits. So, in this sense, both the blue and the green groups are proportionally more distant from the diverse (red) group considering PC1, than they are from each other, considering PC2 (Figure 6), as PC1 accounts for a much higher part of the variation. 


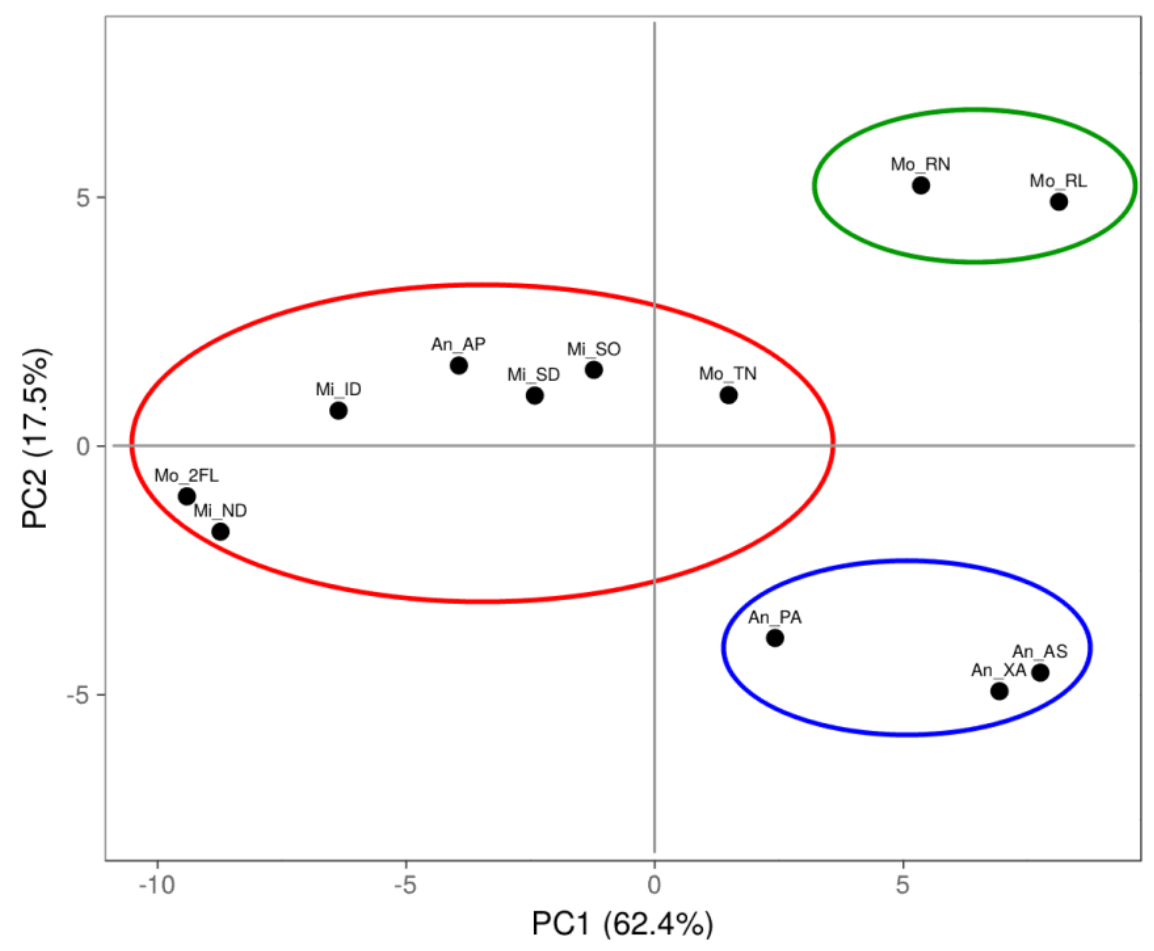

Figure 6. Multivariate analysis of principal components (PCA) pooling all assessed variables. Embrapa Clima Temperado, Pelotas-RS, Brazil, 2020.

\section{Conclusions}

Considering the nature of every set of variables previously discussed (Figures 3 - 5), as well as their interactions (Figure 6), root number and length, area of sclerenchyma and xylem and phloem vessels are proposed to be the most efficient traits to be assessed in detailed studies aiming to identify superior genotypes in rice breeding programs, from the morphophysiological point of view.

\section{References}

Alam, M. M., Karim, M. R., \& Ladha, J. K. (2013). Integration best management practices for rice with farmers' crop management techniques: A potential option for minimizing rice yield gap. Field Crops Research, 144, 62-68. https://doi.org/10.1016/j.fcr.2013.01.010

Aohara, T., Kotake, T., Kaneko, Y., Takatsuji, H., Tsumuraya, Y., \& Kawasaki, S. (2009). Rice BRITTLE CULM 5 (BRITTLE NODE) is Involved in Secondary Cell Wall Formation in the Sclerenchyma Tissue of Nodes. Plant and Cell Physiology, 50(11), 1886-1897, https://doi.org/10.1093/pcp/pcp133

Avolio, M. L., Forrestel, E. J., Chang, C. C., Peirre, K. J. L., Burghardt, K. T., \& Smith, M. D. (2019). Demystifying dominant species. New Phytologist, 233, 1106-1126. https://doi.org/10.1111/nph.15789

Aysajan, A., \& Qingjun, L. (2018). Morphological plasticity and adaptation level of distylous (Primula nivalis) in adaptation in a heterogeneous alpine environment. Plant Diversity, 40, 
284-291. https://doi.org/10.1016/j.pld.2018.11.003

Bailey K. J., \& Leegood, R. C. (2016). Nitrogen recycling from the xylem in rice leaves: dependence upon metabolism and associated changes in xylem hydraulics. Journal of Experimental Botany, 67, 2901-2911. https://doi.org/10.1093/jxb/erw132

Bertolino, L. T., Caine, R. S., \& Gray, J. E. (2019). Impact of Stomatal Density and Morphology on Water-Use Efficiency in Changing World. Frontiers in Plant Science, 10, 1-11. https://doi.org/10.3389/fpls.2019.00225

Brito, G. G., Fagundes, P. R. R., Telo, G. M., Abreu, A. G., Magalhães Jr, A. M., Franco, D. F., ... Petrini J. A. (2016). Impact of supra-optimal temperatures on physiology and yield in rice. Journal of Agricultural Science, 8, 27-37. https://doi.org/10.5539/jas.v8n2p27

Caine, R. S., Yin, X., Sloan, J., Harrison, E. L., Mohammed, U., Fulton, T., ... Gray, J. E. (2019). Rice with reduced stomatal density conserves water and has improved drought tolerance under future climate conditions. New Phytologist, 221, 371-384. https://doi.org/10.1111/nph.15344

Chen, Q., Xie, Q., Gao, J., Wang, Q., Sun, B., Liu, B., ... Zhang, Z. (2015). Characterization of Rolled \& Erect Leaf 1 in regulation leave morphology in rice. Journal of Experimental Botany, 66, 6047-6058. https://doi.org/10.1093/jxb/erv319

Colmer, T. D. (2003). Long-distance transport of gases in plants: a perspective on internal aeration and radial oxygen loss from roots. Plant, Cell and Environment, 26, 17-36. https://doi.org/10.1046/j.1365-3040.2003.00846.x

Crang R., Lyons-Sobaski S., \& Wise, R. (2018). Plant Anatomy. Springer: Champaign. 725 p. https://doi.org/10.1007/978-3-319-77315-5_6

Dittberner, H., Korte, A., Mettler-Alrmann, T., Webe, A. P. M., Monroe, G., \& Meaux, J. (2018). Natural variation in stomata size contributes to the adaptation of water-use efficiency in Arabidopsis thaliana. Molecular Ecology, 27,

4052- 4065. https://doi.org/10.1111/mec.14838

Eom, J., Choi, S., Ward J. M., \& Jeon. J. (2012). The Mechanism of Phloem Loading in Rice (Oryza sativa). Molecules and Cells, 33, 431-438.

https://doi.org/10.1007/s10059-012-0071-9

Fageria, N. K., \& Moreira, A. (2011). The Role of Mineral Nutrition on Root Growth of Crop Plants. https://doi.org/10.1016/B978-0-12-385531-2.00004-9

Faralli, M., Matthews, J., Lawson, T. (2019). Exploiting natural variation and genetic manipulation of stomatal conductance for crop improvement. Current Opinion in Plant Biology, 49, 1-7. https://doi.org/10.1016/j.pbi.2019.01.003

Feldman, A. B., Leung, H., Baraoidan, M., Elmidoro-Mabilangan, A., Canicosa, I., Quick, W. P., ... Murchie, E.H. (2017). Increasing Leaf Vein Density via Mutagenesis in Rice Results in an Enhanced Rate of Photosynthesis, Smaller Cell Sizes and Can Reduce Interveinal 
Mesophyll Cell Number. Frontiers in Plant Science, 8, 1883.

https://doi.org/10.3389/fpls.2017.01883

Flumignan, D. L., Figueiredo, L. H. S., Silva, J. A., Fietz, C. R., \& Comunello, E. (2016). Evapotranspiração de Referência (ET 0 ) na Região de Dourados, Mato Grosso do Sul. Dourados: Embrapa Agropecuária Oeste, 6 p.

Fukagawa, N. K., \& Ziska, L. H. (2019). Rice: Importance for global nutrition. Journal of Nutrition Science and Vitaminology, 65, S2-S3. https://doi.org/10.3177/jnsv.65.S2

Galon, L., Guimarães, S., Radüz, A. L., Burg, G. M., Zandoná, R. R., Bastiani, M. O., ... Perin, G. F. (2015). Relative competitiveness of irrigated rice cultivars and (Aeschynomene denticulata). Bragantia, 74, 67-74. https://doi.org/10.1590/1678-4499.0147

Kato, Y., \& Okami, M. (2010). Root growth dynamics and stomatal behaviour of rice (Oryza sativa L.) grown under aerobic and flooded conditions. Field Crops Research, 117(1), 9-17. https://doi.org/10.1016/j.fcr.2009.12.003

Khan, M. H., Dar, Z., \& Dar, A. (2015). Breeding strategies for improving rice yield. Agricultural Sciences, 06, 467-478. https://doi.org/10.4236/as.2015.65046

Kim, Y., Suk, C., Lee, E., Tripathi. P., Heo. S., \& Kim, K. H. (2020). Root Response to drought stress in rice (Oryza sativa). International Journal of Molecular Sciences, 21, 1513. https://doi.org/10.3390/ijms21041513

Liu, K., He, A., Ye, C., Liu, S., Lu, J., Gao, M., ... Zhang, Y. (2018). Root morphological traits and spatial distribution under different nitrogen treatments and their relationship with grain yield in super hybrid rice. Scientific Reports, 8, 131.

https://doi.org/10.1038/s41598-017-18576-4

Marenco, R. A., \& Lopes, N. F. (2008). Fisiologia vegetal: Fotossíntese, respiração, relações hídricas, e nutrição mineral. Viçosa: UFV.

McAdam, S. A. M., Eléouët, M. P., Best, M., Brodeibb, T. J., Murphy, M. C., Cook, S. D., ... Urquhat, S. (2017). Linking auxin with photosynthetic rate via leaf venation. Plant Physiology, 175, 351-360. https://doi.org/10.1104/pp.17.00535

Muhammad, A. T., Guanglong, Z., Adbul, H., Muhammad, A. W., Muhammad, S., \& Li, Y. (2016). Influence of leaf vein density and thickness on hydraulic conductance and photosynthesis in rice (Oryza sativa L.) during water stress. Nature Scientific Reports, 6, 36894. https://doi.org/10.1038/srep36894

Nawaz, A., \& Farooq, M. (2017). Rice Physiology. In: Rice Production Worldwide. Sprenger, USA. pp. 455-485. https://doi.org/10.1007/978-3-319-47516-5_17

NIH - National Institute of Health. (2020). Image J. Rockville Pike, USA. https://imagej.nih.gov/ij/index.html Access in 15 May 2020.

Parlanti, S., Kudahettige, N. P., Lombardi, L., Mensuali-Sodi, A., Alpi, A., Pereta, P., \& Purcciariello, C. (2011). Distinct mechanisms for aerenchyma formation in leaf sheaths of 
rice genotypes displaying a quiescence or scape strategy for flooding tolerance. Annal of Botany, 107, 1335-1343. https://doi.org/10.1093/aob/mcr086

Peizhou, X., Asif, A., Baolin, H., \& Xianjun, W. (2018). Current advances in molecular basis and mechanisms regulating leaf morphology in rice. Frontiers in Plant Science, 9, 1528. https://doi.org/10.3389/fpls.2018.01528

Pinto, M. A. B, Parfitt, J. M. B., Timm, L. C., Faria, L. C., Concenço, G., Stumpf, L., \& Noremberg, B. G. (2020). Sprinkler irrigation in lowland rice: Crop yield and its components as a function of water availability in different phenological phases. Field Crops Research, 248, 107714. https://doi.org/10.1016/j.fcr.2020.107714

Poli, Y., Balakrishnan, D., Desiraju, S., Panigrahy, S. R. V., Mangrauthia, S. K., Neelanraju, S. (2018). Genotype $\times$ Environment interactions of Nagina22 rice mutants for yield traits under low phosphorus, water limited and normal irrigated conditions. Nature Scientific Reports, 8, 15530. https://doi.org/10.1038/s41598-018-33812-1

R Core Team (2020). R: A language and environment for statistical computing. R Foundation for Statistical Computing, Vienna, Austria. URL https://www.R-project.org/.

Radosevich, S. R., Holt, J., \& Ghersa, C. M. (2007). Ecology of weeds and invasive plants: Relationship to agriculture and natural resource management, 472p. https://doi.org/10.1002/9780470168943.ch7

Ranawake, A. L., Amarasingha, U. G. S., \& Dahanayake, N. (2013). Agronomic characters of some traditional rice (Oryza sativa L.) cultivars in Sri Lanka. Journal of the University of Rohuna, 1, 3-9. https://doi.org/10.4038/jur.v1i1.6150

Rice Commission. (2018). Technical recommendations for rice cultivation in Southern Brazil. Porto Alegre: Sosbai. 209p. https://www.sosbai.com.br/

Schreiber, F., Scherner, A., Andres, A., Concenço, G., \& Goulart, F. (2018). Competitive ability of rice cultivars in the era of weed resistance. In: Dunea D. (Ed.) Plant Competition in Cropping Systems. Rijeka: Intech. 39-58. https://doi.org/10.5772/intechopen.78342

Sriphirom, P., Chidthaison, A., \& Towprayoon, S. (2019). Effect of alternate wetting and drying water management on rice cultivation with low emissions and low water used during wet and dry season. Journal of Cleaner Production, 223, 980-988. https://doi.org/10.1016/j.jclepro.2019.03.212

Steduto, P., Hsiao, T. C., Fereres, E., Raes, D. (2012). Crop yield responses to water. Rome: FAO. 505p. (Publication FAO, $\mathrm{n}^{\mathrm{o}}$ 66). Available at http://www.fao.org

Steffens, B., Geske, T., \& Sauter, M. (2010). Aerenchyma formation in the rice stem and it promotion by H2O2. New Phytologist, 190, 369-378. https://doi.org/10.1111/j.1469-8137.2010.03496.x

Thiel, C. H., David, F. A., Galon, L., Deuner, S., Forte, C. F., Perin, G. F., ... Concenço, G. (2018). Physiology of weed in instraspecific competition. Journal of Agricultural Science, 10, 
334. https://doi.org/10.5539/jas.v10n6p334

Tivet, F., Pinheiro, B. D. S., Raissac, M. D., \& Dingkuhn, M. (2001). Leaf blade dimensions of rice (Oryza sativa L. and Oryza glaberrima Steud.). Relationship between tillers and the main stem. Annals of Botany, 88, 507-11. https://doi.org/10.1006/anbo.2001.1447

Veçozzi, T. A., Sousa, R. O., Scivittaro, W. B., Winert, C., \& Tarrillo, V. R. C. (2017). Soil solution and plant nitrogen on irrigated rice under controlled release nitrogen fertilizers. Ciência Rural 48, e20170279. https://doi.org/10.1590/0103-8478cr20170279

Willian, J. L., Groover, A., Lichtenberger, R., Faruta, K., Yadav, S. R., Helariutta, Y., ... Kachroo, P. (2013). The plant vascular system: evolution, development and functions. Journal of Integrative Plant Biology, 55, 294-388. https://doi.org/10.1111/jipb.12041

Zain, N. A. M., Smail. M. R., Puteh, A., Mahmood, M., \& Islam, M. R. (2014). Impact of cyclic water stress on growth physiological responses and yield of rice (Oryza sativa L.) grown in tropical environment. Ciência Rural, 44, 2136-2141. https://doi.org/10.1590/0103-8478cr20131154

Zhong, X., Peng, S., Sheehy, J., Visperas, R., \& Liu, H. (2002). Relationship between tillering and leaf area index: Quantifying critical leaf area index for tillering in rice. The Journal of Agricultural Science, 138, 269-279. https://doi.org/10.1017/S0021859601001903

Zhou, Q., \& Wang, J. (2011). Comparison of upper leaf and lower leaf of rice plans in response to supplemental nitrogen levels. Journal of Plant Nutrition, 26, 607-617. https://doi.org/10.1081/PLN-120017668

\section{Copyright Disclaimer}

Copyright for this article is retained by the author(s), with first publication rights granted to the journal.

This is an open-access article distributed under the terms and conditions of the Creative Commons Attribution license (http://creativecommons.org/licenses/by/4.0/). 